\title{
CpG methylation of MGMT and hMLHI promoter in hepatocellular carcinoma associated with hepatitis viral infection
}

\author{
S Matsukura', H Soejima*,', T Nakagawachi', H Yakushiji', A Ogawa ${ }^{3}$, M Fukuhara $^{4}$, K Miyazaki $^{2}$, \\ Y Nakabeppu ${ }^{5,6}$, M Sekiguchi $^{7}$ and T Mukai'
}

'Department of Biochemistry, Saga Medical School, 5-I - I Nabeshima, Saga 849-850I, Japan; '2Department of Surgery, Saga Medical School, 5-I-I Nabeshima, Saga 849-8501, Japan; ${ }^{3}$ Department of Pathology, Saga Medical School, 5-I-I Nabeshima, Saga 849-850I, Japan; ${ }^{4}$ Department of Biochemistry, Medical Institute of Bioregulation, Kyushu University, 3-I - I Maedashi, Higashi-ku, Fukuoka 81 2-8582, Japan; ${ }^{5}$ Division of Neurofunctional Genomics, Medical Institute of Bioregulation, Kyushu University, 3-I - I Maedashi, Higashi-ku, Fukuoka 812-8582, Japan; ${ }^{6}$ Core Research for Evolutional Science and Technology, (CREST) of Japan Science and Technology Corporation, Japan; 'Department of Biology and Frontier Research Center, Fukuoka Dental College, 2-15-I Tamura, Sawara-ku, Fukuoka 814-0193, Japan

Inactivations of DNA repair genes, $0^{6}$-methylguanine-DNA methyltransferase (MGMT) and hMLHI, by promoter hypermethylation have been reported in several types of primary human neoplasia. This epigenetic inactivation mechanism remains elusive in hepatocellular carcinoma (HCC). To investigate the relation between the expression of MGMT and hMLHI and the CpG methylation within their promoters in HCCs with or without hepatitis viral infection, we performed immunohistochemistry and urea/bisulphite sequencing on $46 \mathrm{HCCs}$, corresponding noncancerous tissues, and 20 normal liver tissues. MGMT- and hMLHI-negative HCCs were $60.9 \%$ (28 out of 46 ) and $21.8 \%$ ( 10 out of 46 ), respectively. HCCs lacking both proteins were 10.9\% (five out of 46). The frequency and extent of CpG methylation in the MGMT promoter increased along with hepatitis viral infection and pathological progression. MGMT-negative tumours showed very frequent and widespread methylation in the promoter compared with MGMT-positive tumours. Half of the hMLHI-negative HCCs showed promoter hypermethylation. These data suggested that MGMT gene silencing in a subset of HCCs was likely caused by epigenetic alteration, such as promoter hypermethylation, and that the promoter hypermethylation silenced the $h \mathrm{MLHI}$ gene in half of the $\mathrm{hMLHI}$-negative tumours. A correlation between the promoter methylation status and viral infection, although it was weak, intimated that hepatitis viral infections could play a role in the CpG methylation of the MGMT promoter.

British Journal of Cancer (2003) 88, 521 -529. doi: I 0.1038/sj.bjc.6600743 www.bjcancer.com

(c) 2003 Cancer Research UK

Keywords: CPG methylation; MGMT; hMLHI; hepatocellular carcinoma; hepatitis viral infection; urea/bisulphite sequencing

Hepatocellular carcinoma (HCC) is one of the most frequent human malignancies and a major cause of cancer-related deaths worldwide (Okuda et al, 1992). Most HCCs exhibit characteristics compatible with chronic hepatitis and cirrhosis caused by persistent infection of hepatitis B virus (HBV) and/or hepatitis C virus (HCV) (Okuda et al, 1992). Both chronic hepatitis and cirrhosis associated with viral infection are considered as precancerous conditions (Paradis et al, 1998). The process of chronic inflammation or cirrhosis initiates clonal expansion and facilitates regeneration of hepatocytes (Aihara et al, 1994). During neoplastic degenerative change, an accumulation of genetic alterations or epigenetic changes may occur. However, the molecular mechanisms of hepatocarcinogenesis associated with hepatitis viral infection have not been clarified.

$\mathrm{O}^{6}$-methylguanine-DNA methyltransferase (MGMT) is a DNA repair enzyme that plays an important role in the defence against the carcinogenic and cytotoxic effects of alkylating agents in

*Correspondence: Dr H Soejima; E-mail: soejimah@post.saga-med.ac.jp Received 17 June 2002; revised 14 October 2002; accepted 7 November 2002 cellular DNA (Pegg, 1990). Since ubiquitous and environmental alkylating agents such as $\mathrm{N}$-nitroso compounds are principally metabolised and activated in mammalian hepatocytes, liver tissue is persistently exposed to activated alkylating agents (Gerson et al, 1986). It was demonstrated that $\mathrm{Mgmt}$-targeted mice $\left(\mathrm{Mgmt}^{-/-}\right)$ treated with alkylating agents generated hepatocellular carcinoma (Iwakuma et al, 1997). Major and Collier (1998) suggested that MGMT protein activity decreased in chronic hepatitis, cirrhosis, and HCCs. We have recently reported that the MGMT expression was frequently lost in a variety of human tumours and was a significant prognostic factor (Matsukura et al, 2001). Since loss of MGMT expression was not commonly because of a genetic change, it has been suggested that another cause, such as epigenetic change, is involved (Esteller et al, 1999; Bhakat and Mitra, 2000).

Mismatch repair system (MMR) is an essential system by which cells correct errors in DNA replication during proliferation to maintain the fidelity of the genome (Lahue et al, 1989). One of the MMR genes, $h M L H 1$, has been demonstrated to play a pivotal role in DNA MMR (Papadopoulos et al, 1994). In addition, the important association between MGMT and MMR in DNA repair was pointed out by Frayling (1999). Furthermore, it was shown that $\mathrm{Mgmt}^{-/-} \mathrm{Mlh1^{-/- }}$ (double knockout) mice 
Table I Primer sequence and PCR conditions

\begin{tabular}{|c|c|c|}
\hline & Primer sequences & PCR cycles \\
\hline \multicolumn{3}{|l|}{ MGMT } \\
\hline SI & $\begin{array}{l}\text { TTGGAIGGTATIGTTATTATAGG } \\
\text { AATAAATAAAAATCAAAACIACCC }\end{array}$ & 40 cycles of $95^{\circ} \mathrm{C} / 30 \mathrm{~s}, 50^{\circ} \mathrm{C} / 30 \mathrm{~s}, 72^{\circ} \mathrm{C} / 90 \mathrm{~s}$ \\
\hline \multicolumn{3}{|c|}{ e } \\
\hline $\begin{array}{l}\text { S2 } \\
\text { AS2 }\end{array}$ & $\begin{array}{l}\text { TTATTATAGGTIITGGAGGTTGTTT } \\
\text { AAAAATCAAAACIACCCCCC }\end{array}$ & 30 cycles of $95^{\circ} \mathrm{C} / 30 \mathrm{~s}, 60^{\circ} \mathrm{C} / 30 \mathrm{~s}, 72^{\circ} \mathrm{C} / 60 \mathrm{~s}$ \\
\hline \multicolumn{3}{|l|}{ hMLHI } \\
\hline SI & $\begin{array}{l}\text { GAIGTITATATGTTIGGGTAGTAT } \\
\text { ACCACIAACIACATTTTAACICC }\end{array}$ & 40 cycles of $95^{\circ} \mathrm{C} / 30 \mathrm{~s}, 50^{\circ} \mathrm{C} / 30 \mathrm{~s}, 72^{\circ} \mathrm{C} / 90 \mathrm{~s}$ \\
\hline \multicolumn{3}{|l|}{ 2nd PCR } \\
\hline $\begin{array}{l}\text { S2 } \\
\text { AS2 }\end{array}$ & $\begin{array}{l}\text { TITTATTTAGTIGIGATITITA } \\
\text { CAAAAAAACCAAAAAAACITCTAAA }\end{array}$ & 30 cycles of $95^{\circ} \mathrm{C} / 30 \mathrm{~s}, 52^{\circ} \mathrm{C} / 30 \mathrm{~s}, 72^{\circ} \mathrm{C} / 60 \mathrm{~s}$ \\
\hline \multicolumn{3}{|c|}{ Colony PCR } \\
\hline $\begin{array}{l}\text { VSI } \\
\text { VASI }\end{array}$ & $\begin{array}{l}\text { TCCGGCTCGTATGTTGTGTGGA } \\
\text { GTGCTGCAAGGCGATTAAGTTGG }\end{array}$ & 20 cycles of $96^{\circ} \mathrm{C} / 20 \mathrm{~s}, 60^{\circ} \mathrm{C} / 20 \mathrm{~s}, 72^{\circ} \mathrm{C} / 120$ \\
\hline
\end{tabular}

I=inosine.
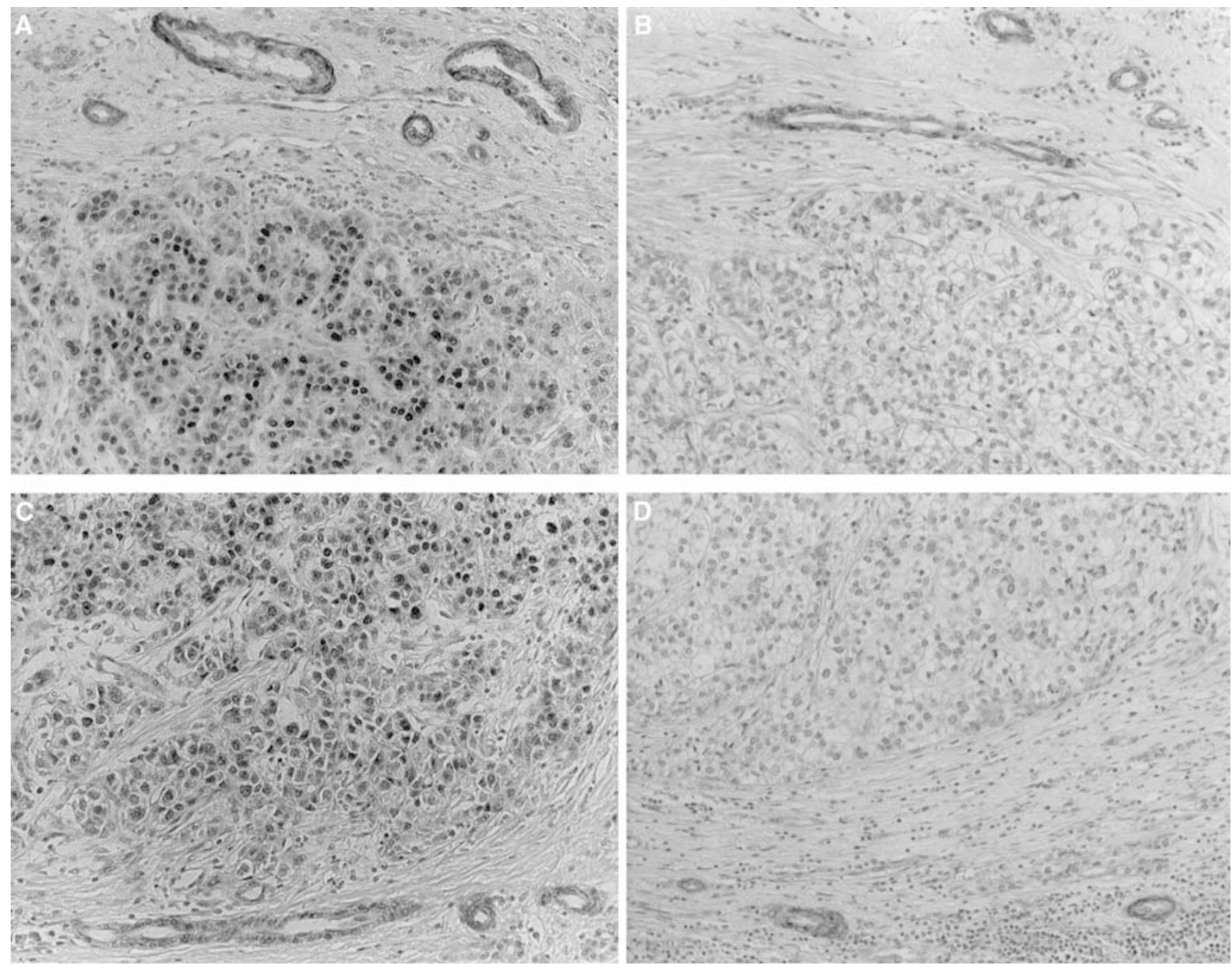

Figure I Immunohistochemical staining of MGMT (A, B) and hMLHI (C, D) in HCCs. MGMT- or hMLHI-positive tumour cells showed strongly stained nuclei $(\mathbf{A}, \mathbf{C})$, while no stained nucleus was detected in MGMT- or hMLHI-negative tumours (B, D), except for bile duct cells as an internal positive control. 
treated with alkylating agents exhibited high susceptibility to carcinoma (Kawate et al, 1998). It is, however, unclear whether tumours expressing neither of the genes exist in human HCCs.

It has been proposed that aberrant DNA methylation of $\mathrm{CpG}$ islands in the promoter region is correlated with inactivation of tumour suppressor genes in human cancer. Esteller et al. (2001) have demonstrated the reduced expression of tumour suppressor genes such as $p 16, M G M T$, and $h M L H 1$ by promoter hypermethylation in several human neoplasias, and have suggested that this epigenetic change might be an early event in the pathogenesis of several human tumours. Recently, the correlation of $p 16$ promoter hypermethylation with chronic hepatitis and cirrhosis associated with $\mathrm{HBV}$ or $\mathrm{HCV}$ infection has been reported (Kaneto et al, 2001).
Here, we report the existence of human HCCs lacking both MGMT and hMLH1 proteins, the relation between HCCs associated with hepatitis viral infection and detailed CpG methylation status of $M G M T$ and $h M L H 1$ promoter regions, and the specific CpG methylation pattern of MGMT- and hMLH1negative tumours.

\section{MATERIALS AND METHODS}

\section{Tissue specimens}

A total of 46, HCCs and adjacent noncancerous liver tissues (mean age 63.8 years; 35 males and 11 females; seven HBV positives, 33 $\mathrm{HCV}$ positives, one $\mathrm{HBV} / \mathrm{HCV}$ positive and five $\mathrm{HBV} / \mathrm{HCV}$

Table 2 Background of patients with hepatocellular carcinomas

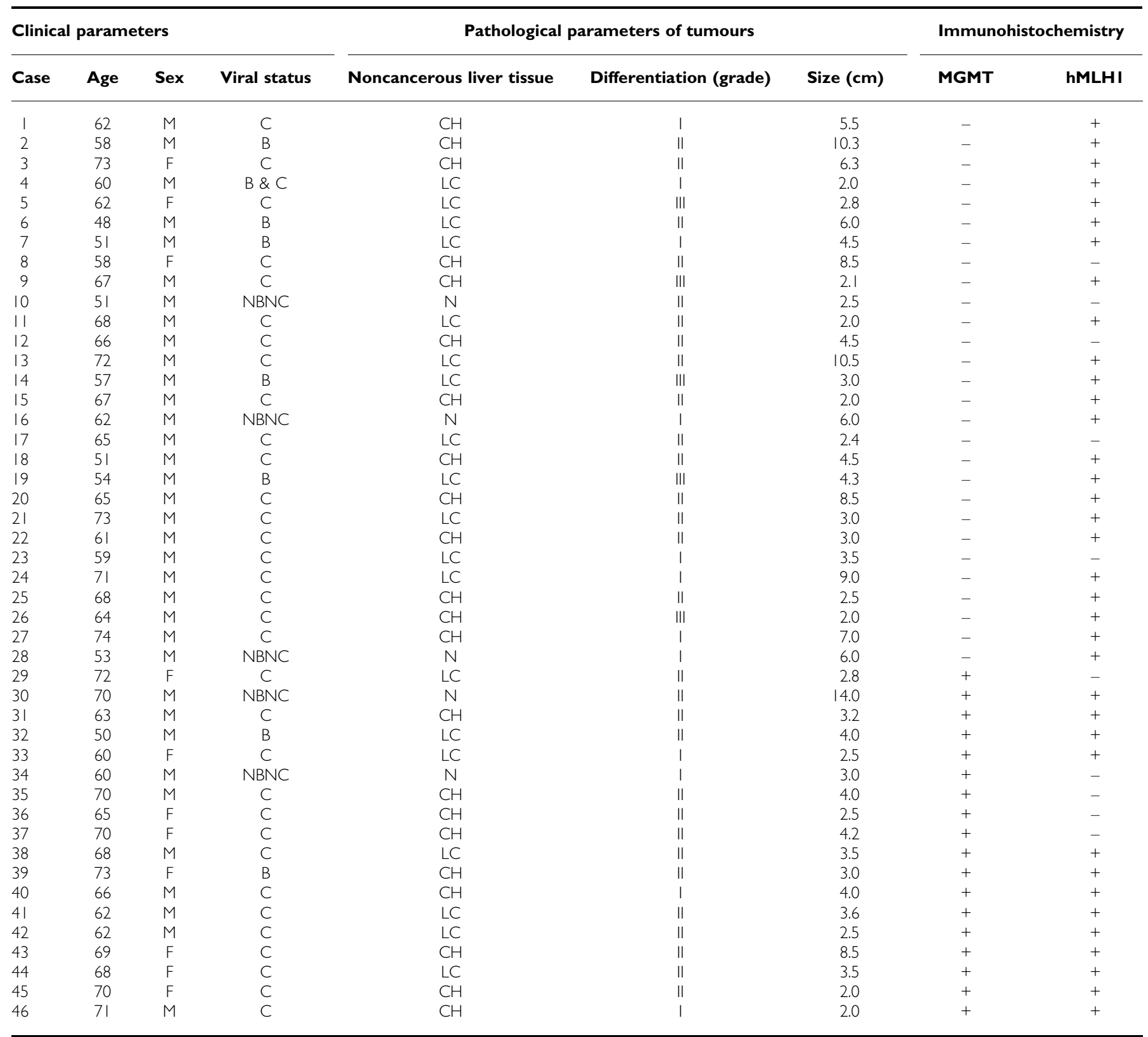

Viral status $\mathrm{B}=\mathrm{HBs} \mathrm{Ag}$ positive; $\mathrm{C}=\mathrm{HCV}$ antibody positive; $\mathrm{NBNC}=\mathrm{HBs} \mathrm{Ag}$ and $\mathrm{HCV}$ antibody negative; $\mathrm{CH}=$ chronic hepatitis; $\mathrm{LC}=$ liver cirrhosis; $\mathrm{N}=$ normal liver, grade $\mathrm{I}=$ welldifferentiated HCC; grade $\|=$ moderately differentiated HCC; grade III=poorly differentiated HCC; +=positive; -=negative. 
negatives) and 20 normal liver (mean age 59.9 years; 14 males and six females) tissue specimens were obtained surgically and frozen at $-80^{\circ} \mathrm{C}$. All specimens were subjected to pathological diagnosis. DNAs of all tumour samples were extracted from pathologically obvious cancerous regions in the resected liver. HBV and HCV infections were diagnosed serologically with HBs antigen (LPIA200; Diatron Laboratories, Tokyo, Japan) and anti-HCV antibody (Immunocheck-HCV Ab; International Reagent, Kobe, Japan), respectively. Informed consent was obtained from all patients.

\section{Anti-MGMT antibody}

Polyclonal rabbit antibodies against human MGMT protein were prepared using TrpE fusion protein, as described (Nakabeppu and Nathans, 1991). Escherichia coli BL21 (DE3) carrying pET3d:TrpEhMGMT-1 that encodes the TrpE polypeptide fused to a region of MGMT (residues 1-45) at the C terminus was used to produce each fusion protein (Studier et al, 1990), and polyclonal antibodies against the fusion protein were raised in rabbits. The serum was initially applied to a TrpE-hMGMT-1-coupled column; their bound materials were eluted at $\mathrm{pH} 2.3$ and dialysed against $10 \mathrm{~mm}$ Tris$\mathrm{HCl}(\mathrm{pH} 7.4)$ and $150 \mathrm{~mm} \mathrm{NaCl}$. To increase antibody specificity, the eluted fraction was applied to an affinity column with TrpEmMGMT-1, in which a corresponding region of mouse MGMT (residues 1-58) was fused to TrpE (Kawate et al, 1995), as a ligand. Then the bound fraction was eluted and dialysed. This fraction was used as an anti-MGMT antibody. The specificity of the antibody has been reported previously (Matsukura et al, 2001).

\section{Immunohistochemistry}

Immunohistochemical studies for MGMT (Matsukura et al, 2001) and hMLH1 (Wang et al, 2001) were performed as described previously. In the present study, mouse monoclonal antibody against hMLH1 protein (clone G168-728; PharMingen, San Diego, CA, USA) (Wang et al, 2001) was used. Positive staining was identified by the presence of brown staining in the nucleus and/or cytoplasm. MGMT and hMLH1 expression were evaluated as positive if the distribution of stained cells was more than $10 \%$ of cancer cells. The expression status of MGMT and hMLH1 was assessed by two pathologists without a knowledge of the clinicopathological features of the case or the clinical outcome.

\section{Urea/bisulphite modification of DNA and PCR amplification}

The urea/bisulphite treatment of genomic DNA was performed as described by Paulin et al (1998). The modified DNA was
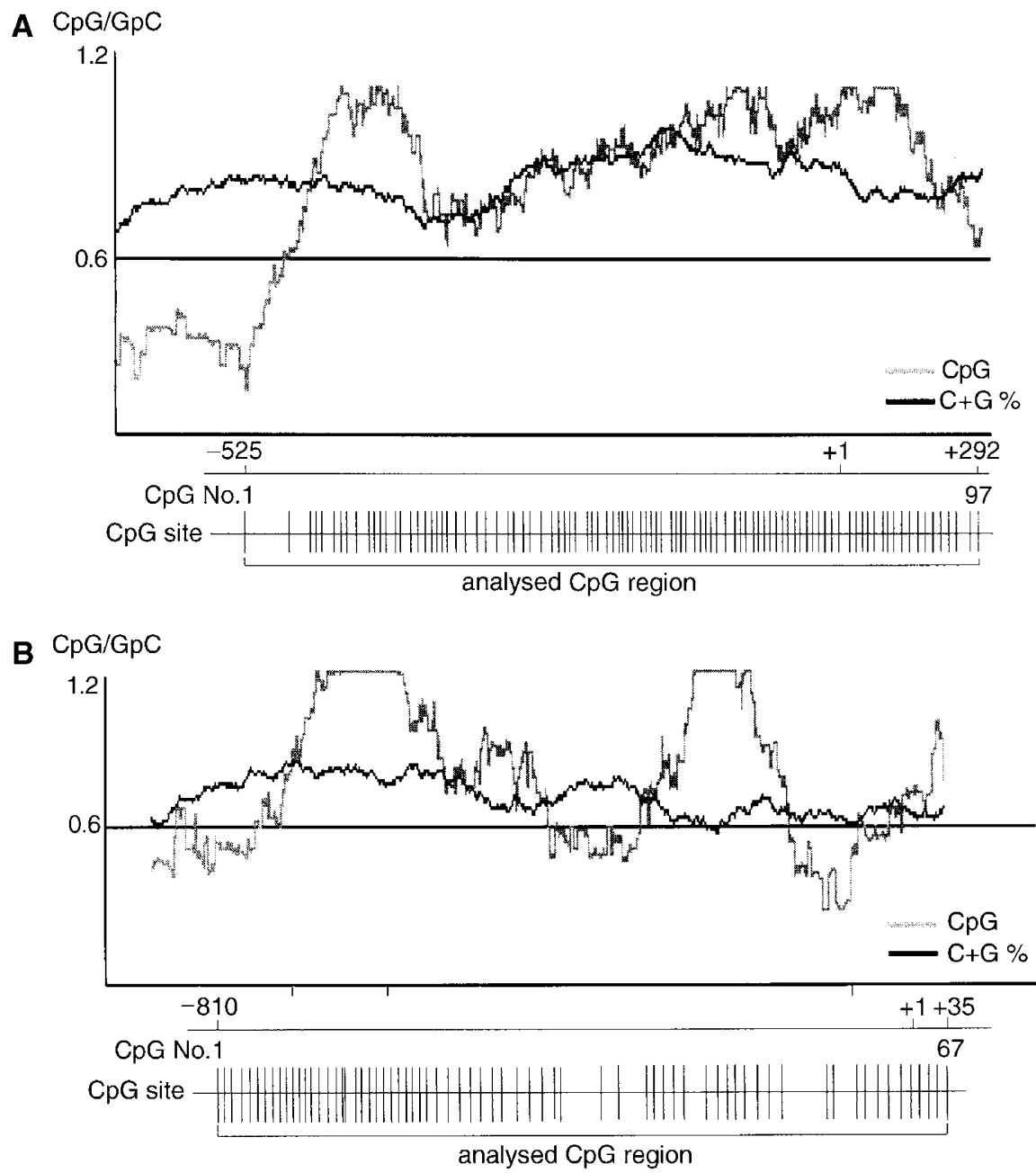

Figure $2 \mathrm{CpG}$ island of the MGMT and hMLHI promoter region. (A) Schematic representation of the MGMT CpG island containing $97 \mathrm{CpG}$ sites, spanning $-525 \mathrm{nt}$ to $+292 \mathrm{nt}$, relative to the transcriptional start site $(+\mathrm{I})$. (B) Schema of the CpG island in $\mathrm{hMLHI}$ containing $67 \mathrm{CpG}$ sites, spanning $-8 \mathrm{I} 0$ nt to $+35 \mathrm{nt}$. Vertical bars denote the location of each CpG site. The graph shows the CpG island defined by Gardiner-Garden and Frommer of a region greater than 200 bp with a high GC content (grey line, number of CpG; black line, the frequency of C+G) and an observed/expected ratio for the occurrence of CpG more than 0.6 . 
resuspended in $20 \mu \mathrm{l}$ of water and immediately subjected to PCR or stored at $-20^{\circ} \mathrm{C}$. The whole $\mathrm{CpG}$ island in the $M G M T$ promoter region was amplified by nested PCR (Figure 2A). Primer sequences and PCR conditions are presented in Table 1 . The first round of amplification was performed with $50 \mathrm{ng}$ of the bisulphite-treated DNA. Then 1/1000th of the first PCR product was subjected to the second round PCR. The size of the nested PCR product was $835 \mathrm{bp}$. The CpG island of $h M L H 1$ was also amplified by nested PCR (Figure 2B). The size of the nested PCR product was $815 \mathrm{bp}$.

\section{Cloning of PCR product and sequencing}

The amplicons were cloned into the pSTBlue-1 Acceptor ${ }^{\mathrm{TM}}$ Vector (Novagen Inc., Madison, WI, USA) to transform competent JM109 cells (Wako Pure Chemical Industries, Ltd, Osaka, Japan). The plasmid DNAs were amplified by colony PCR reactions (Table 1). A total of 10 of the colony PCR products from each sample were sequenced.

\section{Statistical analysis}

Differences among groups (normal liver tissues $v s$ chronic hepatitis, liver cirrhosis and HCC, or MGMT-negative vs -positive HCCs) were tested by one-way analysis of variance (ANOVA). Probability levels of $<0.05$ were considered statistically significant.

\section{RESULTS}

\section{Immunohistochemistry of MGMT and hMLH1}

Immunohistochemical analysis was performed on normal liver, noncancerous tissues, and HCCs to examine whether MGMT and hMLH1 were expressed. Expression of these proteins was detected in cells from normal liver, as well as in chronic hepatitis and liver cirrhosis, including hepatocytes, bile duct cells, vascular endothelial cells, smooth muscle, and so on (data not shown). We used bile duct cells as an internal positive control within the sections because these cells in cancerous regions also commonly expressed MGMT and hMLH1 (Figure 1B, D). The signals of MGMT-positive tumour cells were as intense as those of the bile duct cells (Figure 1A), while those of MGMT-negative tumour cells were virtually undetectable (Figure 1B). As for hMLH1, signal intensity similar to those of bile duct cells was detected in hMLH1-positive tumour cells (Figure 1C), but not in hMLH1-negative tumours (Figure 1D). MGMT- and hMLH1negative tumours were $60.9 \%$ (28 out of 46 ) and $21.8 \%$ (10 out of 46), respectively. Tumours lacking both proteins were $10.9 \%$ (5 out of 46 ) of all tumours. The results of immunohistochemistry and the characteristics of patients with HCC are shown in Table 2.

\section{Methylation analysis of MGMT promoter region in HCCs, noncancerous, and normal liver tissues}

Next, we performed urea/bisulphite sequencing to investigate the methylation status of MGMT and $h M L H 1$ promoter region in HCCs, noncancerous tissues, and normal liver. Prior to the study of primary samples, to confirm that the nested PCR we used could accurately reflect the methylation status of genomic DNA, we performed PCR using DNA solutions containing methylated and unmethylated genomic DNAs with different ratios. The methylated and unmethylated DNAs were extracted from an MGMT-deficient cell line, SW48 (Aquilina et al, 1998), in which the MGMT promoter was fully methylated and an MGMT-proficient cell line, HepG2 (Fritz and Kaina, 1992), in which the promoter was not methylated at all. We found that the ratio of methylated to unmethylated clones obtained from the nested PCR-cloningsequencing was consistent with the theoretical ratio (data not shown).

The CpG island of MGMT including $97 \mathrm{CpG}$ sites is shown in Figure 2A. We examined the detailed methylation status of all $\mathrm{CpG}$ sites by urea/bisulphite DNA sequencing in 46 HCCs (Figure $3 \mathrm{~A}$ ), corresponding noncancerous tissues (Figure 3B), and 20 normal liver tissues (Figure 3C). The methylation was somewhat observed at the $5^{\prime}$ border of the $\mathrm{CpG}$ island irrespective of cancerous or noncancerous samples. These methylated CpGs in MGMT-positive tumours, noncancerous tissues except for $4 \mathrm{NC}$ and $5 \mathrm{NC}$, and normal tissues never extended beyond the first nine CpGs. However, a subset of MGMT-negative HCCs, 1C-15C, showed that the methylation extended in the $3^{\prime}$ direction beyond the first nine CpGs. Tumour 1C showed all 97 hypermethylated CpG sites in the island (data not shown). Other MGMT-negative tumours, $16 \mathrm{C}-28 \mathrm{C}$, showed a similar extent of methylation to MGMTpositive tumours and normal tissues.

From the point of view of hepatitis viral infection, the methylation frequency at particular CpG sites in chronic hepatitis, liver cirrhosis, and HCC was higher than that in normal liver with statistical significance (Figure 4A). The frequency at those sites increased along with pathological progression. Furthermore, the methylation also extended towards downstream along with pathological progression (Figure 4A). These data suggested that hepatitis viral infection might be involved in methylation of the MGMT promoter region. As for MGMT expression, MGMTnegative tumours showed high frequency and widespread methylation compared with MGMT-positive tumours and normal liver (Figure 4B). There were significant statistical differences in the methylation frequency at many CpG sites between MGMT-negative and -positive HCCs. This result suggested that hypermethylation of the MGMT promoter might play some role in the lack of MGMT expression. Although we did not use the microdissection method, our results might be of less estimation because of the existence of nontumour DNA. If it is removed, further significant differences could be obtained.

\section{Methylation analysis of $h M L H 1$ promoter region in HCCs, noncancerous, and normal liver tissues}

The CpG island of $h M L H 1$ including $67 \mathrm{CpG}$ sites is shown in Figure 2B. All of the CpG sites were also analysed by urea/ bisulphite sequencing. In all, 10 hMLH1-negative HCCs were detected by immunohistochemistry, and five of these showed promoter hypermethylation (Figure 5). The methylation patterns of these tumours were particular, that is, the middle portion of the $\mathrm{CpG}$ island was methylated and the methylation frequency of each CpG site in the region was approximately $60 \%$. There was no methylated CpG in hMLH1-positive HCCs, noncancerous regions, and normal liver tissues (data not shown).

\section{DISCUSSION}

To date, it is thought that inactivation of the MGMT gene is because of epigenetic changes such as DNA methylation (Esteller et al, 1999, 2001) or some other unknown mechanisms because the genetic change is uncommon. Although the methylation of $M G M T$ and $h M L H 1$ promoter was analysed previously in HCCs, the method used was mostly methylation-specific PCR (MSP) (Esteller et al, 2001). No study has identified critical sites by a survey of detailed methylation of the promoter regions of these genes. This is the first study to examine the detailed $\mathrm{CpG}$ methylation status of $M G M T$ and $h M L H 1$ promoter regions in HCCs, their adjacent tissues, and normal liver tissues.

We compared MGMT-negative and -positive HCCs in order to determine the critical CpG site for the MGMT silencing. A subset of 
A

CpC No.12345678910 $\quad 15 \quad 20 \quad 25 \quad 29$
B

CpG No. $12345678910 \quad 15 \quad 20 \quad 25 \quad 29$

1NC 0000000000000000000000000000 2NC 0000000000000000000000000000

3NC 0000000000000000000000000000

4NC 0000000000000000000000000000

5NC 10000000000000000000000000000

6NC 0000000000000000000000000000

7NC 0000000000000000000000000000

8NC 000000000000000000000000000

9NC 00000000000000000000000000000

10NC 1000000000000000000000000000

$11 \mathrm{NC} 00000000000000000000000000000$

12NC 1000000000000000000000000000

13NC 00000000000000000000000000000

14NC 00000000000000000000000000000

15NC 0000000000000000000000000000

$16 \mathrm{NC} 000000000000000000000000000$

$17 \mathrm{NC} 0000000000000000000000000000$

$18 \mathrm{NC} 0000000000000000000000000$

19NC 000000000000000000000000000

20NC 0000000000000000000000000000

$21 \mathrm{NC} 000000000000000000000000000$ 22NC 0000000000000000000000000000

23NC 1000000000000000000000000000 24NC 00000000000000000000000000000

25NC 10000000000000000000000000000

26NC 100000000000000000000000000

27NC 00000000000000000000000000000 28NC 10000000000000000000000000000 29NC 10000000000000000000000000000 30NC 10000000000000000000000000000 $31 \mathrm{NC} 00000000000000000000000000000$ 32NC 0000000000000000000000000000 $33 \mathrm{NC} 00000000000000000000000000000$ $34 \mathrm{NC} 00000000000000000000000000000$ 35NC 00000000000000000000000000000 $36 \mathrm{NC} 00000000000000000000000000000$ $37 \mathrm{NC} 0000000000000000000000000000$ $38 \mathrm{NC} 00000000000000000000000000000$ $39 \mathrm{NC} 00000000000000000000000000000$ 40NC 90000000000000000000000000000 $41 \mathrm{NC} 0000000000000000000000000000$ 42NC 00000000000000000000000000000 43NC 00000000000000000000000000000 44NC 00000000000000000000000000000 45NC 00000000000000000000000000000 46NC 00000000000000000000000000000
C
CpG No.12345678910
15
20

Nor1 (78) 00000000000000000000000000000 Nor2 (76) Nor3 (66) 100000000000000000000000000 Nor4 (66) 10000000000000000000000000000 Nor5 (66) 10000000000000000000000000000 Nor6 (65) 1090000000000000000000000000 Nor7 (65) 000000000000000000000000000 Nor8 (65) 1000000000000000000000000000 Nor9 (63) 0000000000000000000000000000 Nor10(62) 10000000000000000000000000000 Nor11(62) 0000000000000000000000000000 Nor12(57) 10000000000000000000000000000 Nor13(56) 00000000000000000000000000 Nor14(54) 10000000000000000000000000000 Nor15(53) 1000000000000000000000000000 Nor16(52) 10000000000000000000000000000 Nor17(51) 1000000000000000000000000000 Nor18(48) 1000000000000000000000000000 Nor19(47) 10000000000000000000000000000 Nor20(46) 10000000000000000000000000000

Figure 3 Detailed CpG (No. I -29) methylation status of all analysed 97 CpGs within the MGMT promoter region in HCCs (A), adjacent tissues (B), and normal liver $(\mathbf{C})$. Each circle graph represents the percentage of methylated clones (number of methylated clones/I0 analysed clones $\times 100$ ). Age in parentheses $(\mathbf{C})$ 
MGMT-negative tumours showed a high frequency of methylation within CpGs No. 1-9 and a wide extent of methylation beyond CpG No. 10. This evidence suggested that there were important $\mathrm{CpG}(\mathrm{s})$ for gene silencing in the promoter region. It was known that the $M G M T$ enhancer, corresponding to our analysed CpGs No. $78-90$, existed in the first intron. So far, the methylation of the enhancer (Harris et al, 1994) has not been reported in liver tumours by MSP (Esteller et al, 2001), and we also could not find any methylated CpG in the enhancer, except for sample 1C. It was reported that a single-site methylation upstream of the $p 53$ promoter, not in the enhancer (Lozano and Levine, 1991), reduced its expression during hepatocarcinogenesis in vivo (Pogribny et al, 2000). Therefore, it is possible that the methylation of specific CpG site(s) in the MGMT promoter, aside from the enhancer, could result in downregulation of MGMT gene expression in HCCs. Since we found that some MGMT-negative tumours did not show the very frequent and widespread methylation status, not only DNA methylation but also histone deacetylation, chromatin remodelling, post-transcriptional, and post-translational inactivation might be correlated with the MGMT deficiency. MGMT is converted to an inactive form after removing the methyl group from $O^{6}$-methylguanine (Ishibashi et al, 1994). The inactivated MGMT is not degraded but remains in an immunoreactive state in normal cells (Liu et al, 2001), whereas it is degraded rapidly via the ubiquitin proteolytic pathway in tumour cells (Srivenugopal et al, 1996; Liu et al, 2001). In the light of this, some tumours that correspond to HCCs, $16 \mathrm{C}-28 \mathrm{C}$, might be regarded as MGMTnegative because of the rapid degradation of the inactive form, although the gene might have been transcribed.

Our careful analysis revealed that both the frequency and extent of MGMT methylation increased along with pathological progression. Although little is known of the link between hepatitis viral infections and the methylation machinery of endogenous genes, our findings intimated that $\mathrm{CpG}$ methylation of the MGMT gene

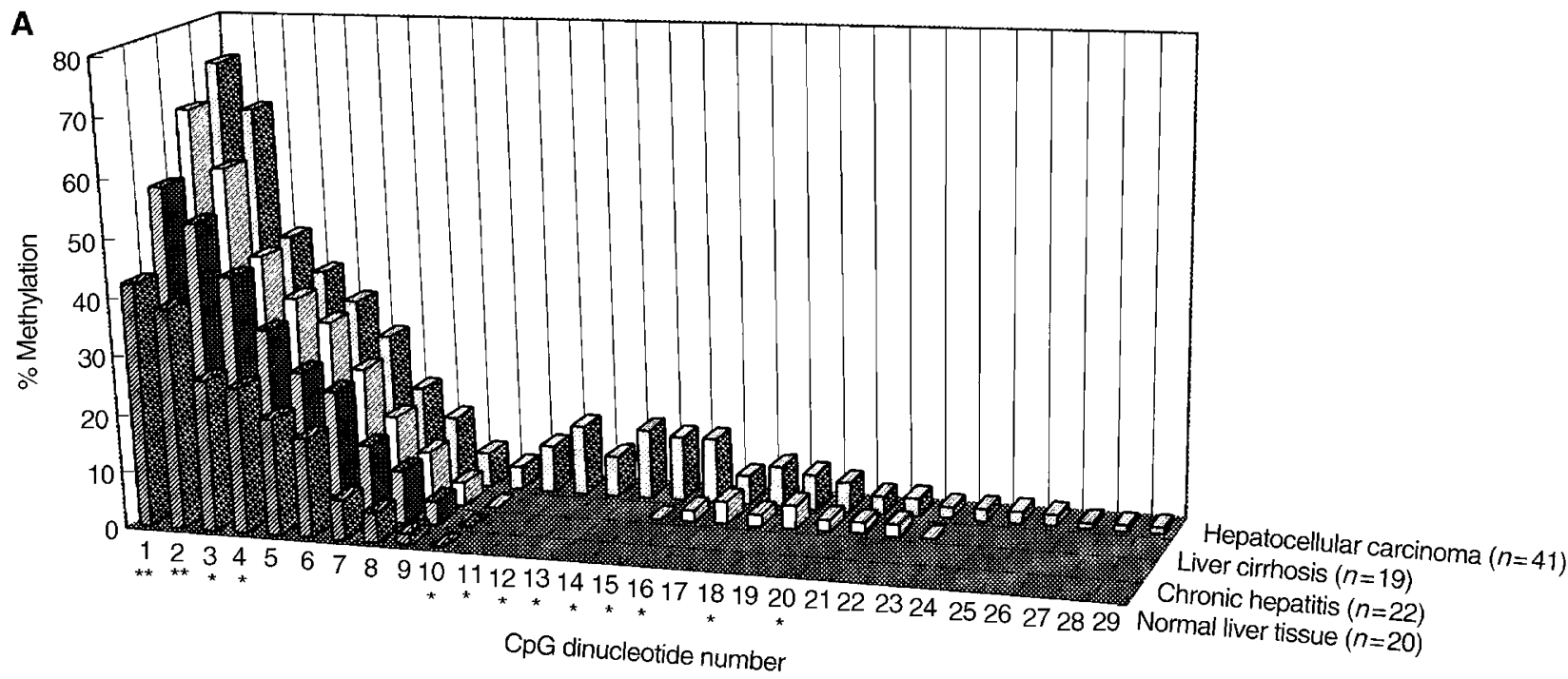

B

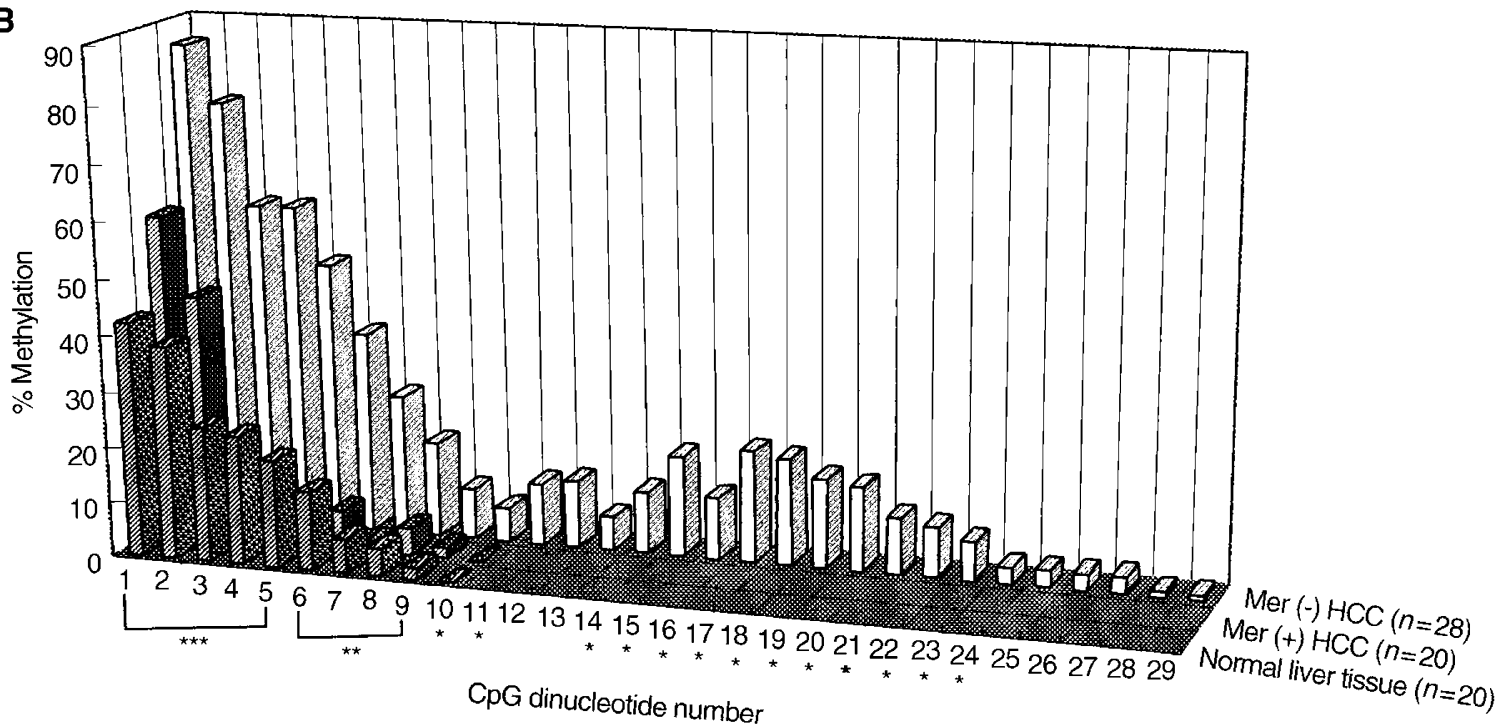

Figure 4 Frequency of methylation (\%) of CpG sites (No. I-29) in MGMT promoter region. (A) Methylation frequency of HCCs, liver cirrhosis, chronic hepatitis with hepatitis viral infection, and normal liver tissues without infection were compared. $* P<0.05$ and $* * P<0.0$ I indicate the significant differences of methylation frequency of each pathological stage vs that of normal liver at the CpG site. (B) Methylation frequencies of MGMT-negative (Mer(-)) HCCs, MGMT-positive (Mer (+)) HCCs, and normal liver tissues were compared. Frequency was calculated by (total number of methylated clones/I0 analysed clones $\times$ case number at each $C p G$ site $) \times 100$. $* P<0.05$, ** $P<0.01$, and $* * * P<0.001$ indicate the significant differences of methylation frequency of Mer (+) HCC vs Mer (-) HCC at CpG site. 


\begin{abstract}
CpG No. 1415
20

25

30

35

40

45

50

23C 0000000000000000000000000000000000000000000

55

60

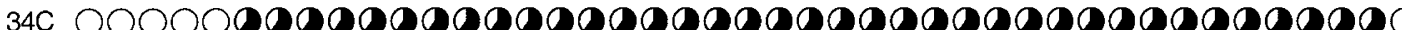
10C 0000000000000000000000000000000000000000000000000 12C 0000000000000000000000000000000000000000000000000 8c 0000000000000000000000000000000000000000000000000 17c 0000000000000000000000000000000000000000000000000 35c 0000000000000000000000000000000000000000000000000 29C 0000000000000000000000000000000000000000000000000 36c 0000000000000000000000000000000000000000000000000 37c 0000000000000000000000000000000000000000000000000
\end{abstract}

Figure 5 Detailed CpG (No. |4-6I) methylation status of all analysed 67 CpGs within the hMLHI promoter region in $10 \mathrm{hMLHI}$-negative HCCs. Each circle graph represents the percentage of methylated clones (number of methylated clones/ 10 analysed clones $\times 100$ ).

was associated with hepatitis viral infections. The levels of DNA methyltransferase mRNA in chronic hepatitis, cirrhosis, and HCCs associated with hepatitis viral infections increased compared with those in normal liver tissues (Sun et al, 1997). Human immunodeficiency virus induced the methylation of interferon $\gamma$ (IFNG) through increased DNA methyltransferase activity (Mikovits et al, 1998). Therefore, CpG methylation of the MGMT promoter could possibly be caused by elevated DNA methyltransferase activity in hepatocarcinogenesis. In contrast to the $M G M T$, there was no methylation in $h M L H 1$-positive HCCs, noncancerous, and normal liver tissues with or without hepatitis viral infection (data not shown), suggesting no relation between hMLH1 promoter methylation and viral infections. The methylation mechanism for $h M L H 1$ should be different from that for MGMT. In the present study, the frequency of $h M L H 1$ promoter hypermethylation in HCCs was $10.9 \%$ (five out of 46) - half of

\section{REFERENCES}

Aihara T, Noguchi S, Sasaki Y, Nakano H, Imaoka S (1994) Clonal analysis of regenerative nodules in hepatitis $\mathrm{C}$ virus-induced liver cirrhosis. Gastroenterology 107: 1805-1811

Aquilina G, Ceccotti S, Martinelli S, Hampson R, Bignami M (1998) N-(2chloroethyl)- $N^{\prime}$-cyclohexyl- $N$-nitrosourea sensitivity in mismatch repairdefective human cells. Cancer Res 58: 135-141

Bhakat KK, Mitra S (2000) Regulation of the human $O^{6}$-methylguanineDNA methyltransferase gene by transcriptional coactivators cAMP response element-binding protein-binding protein and $\mathrm{p} 300 . \mathrm{J}$ Biol Chem 44: 34197-34204

Cunningham JM, Christensen ER, Tester DJ, Kim CY, Roche PC, Burgart LJ, Thibodeau SN (1998) Hypermethylation of the hMLH1 promoter in colon cancer with microsatellite instability. Cancer Res 58: 3455-3460

Esteller M, Corn PG, Baylin SB, Herman JG (2001) A gene hypermethylation profile of human cancer. Cancer Res 61: 3225-3229

Esteller M, Hamilton SR, Burger PC, Baylin SB, Herman JG (1999) Inactivation of the DNA repair gene $O^{6}$-methylguanine-DNA methyltransferase by promoter hypermethylation is a common event in primary human neoplasia. Cancer Res 59: 793-797

Frayling IM (1999) Microsatellite instability. Gut 45: 1-4

Fritz G, Kaina B (1992) Genomic differences between $O^{6}$-methylguanineDNA methyltransferase proficient $\left(\mathrm{Mex}^{+}\right)$and deficient $\left(\mathrm{Mex}^{-}\right)$cell lines: possible role of genetic and epigenetic changes in conversion of $\mathrm{Mex}^{+}$ into $\mathrm{Mex}^{-}$. Biochem Biophys Res Commun 183: 1184-1190

Gerson SL, Trey JE, Miller K, Berger NA (1986) Comparison of $O^{6}$. alkylguanine-DNA alkyltransferase activity based on cellular DNA content in human, rat and mouse tissues. Carcinogenesis 7: 745-749

Harris LC, Remack JS, Brent TP (1994) Identification of a 59 bp enhancer located at the first exon/intron boundary of the human $O^{6}$-methylguanine DNA methyltransferase gene. Nucleic Acids Res 22: 4614-4619

Ishibashi T, Nakabeppu Y, Sekiguchi M (1994) Artificial control of nuclear translocation of DNA repair methyltransferase. J Biol Chem 269: $7645-7650$
hMLH1-negative HCCs - and consistent with the previous finding, $10.0 \%$ (two out of 20) (Esteller et al, 2001). There was no promoter methylation in the remaining five hMLH1-negative HCCs. In colon cancer, gene mutations were found in $h M L H 1$-negative tumours without promoter hypermethylation (Cunningham et al, 1998). Although we did not investigate the gene mutations in those HCCs, genetic alterations would be involved in hMLH1-negative HCCs without promoter hypermethylation.

\section{ACKNOWLEDGEMENTS}

We thank Dr S Kido for taking a photograph of immunohistochemistry. We also thank the members of the Department of Biochemistry, Surgery, and Pathology of Saga Medical School for their helpful advice and assistance.
Iwakuma T, Sakumi K, Nakatsuru Y, Kawate H, Igarashi H, Shiraishi A, Tsuzuki T, Ishikawa T, Sekiguchi M (1997) High incidence of nitrosamine-induced tumorigenesis in mice lacking DNA repair methyltransferase. Carcinogenesis 18: $1631-1635$

Kaneto H, Sasaki S, Yamamoto H, Itoh F, Toyota M, Suzuki H, Ozeki I, Iwata N, Ohmura T, Satoh T, Karino Y, Satoh T, Toyota J, Satoh M, Endo T, Omata M, Imai K (2001) Detection of hypermethylation of the p $16^{I N K 4 A}$ gene promoter in chronic hepatitis and cirrhosis associated with hepatitis B or C virus. Gut 48: $372-327$

Kawate H, Ihara K, Kohda K, Sakumi K, Sekiguchi M (1995) Mouse methyltransferase for repair of $O^{6}$-methylguanine and $O^{4}$-methylthymine in DNA. Carcinogenesis 16: 1595-1602

Kawate H, Sakumi K, Tsuzuki T, Nakatsuru Y, Ishikawa T, Takahashi S, Takano H, Noda T, Sekiguchi M (1998) Separation of killing and tumorigenic effects of an alkylating agent in mice defective in two of the DNA repair genes. Proc Natl Acad Sci USA 95: $5116-5120$

Lahue RS, Au KG, Modrich P (1989) DNA mismatch correction in a defined system. Science 245: $160-164$

Liu L, Spiro TP, Qin X, Majka S, Haaga J, Schupp J, Willson JK, Gerson SL (2001) Differential degradation rates of inactivated alkyltransferase in blood mononuclear cells and tumors of patients after treatment with $O^{6}$ benzylguanine. Clin Cancer Res 7: 2318-2324

Lozano G, Levine AJ (1991) Tissue-specific expression of $p 53$ in transgenic mice is regulated by intron sequences. Mol Carcinogen 4: 3-9

Major GN, Collier JD (1998) Repair of DNA lesion $O^{6}$-methylguanine in hepatocellular carcinogenesis. J Hepatobiliary Pancreat Surg 5: $355-366$

Matsukura S, Miyazaki K, Yakushiji H, Ogawa A, Harimaya K, Nakabeppu $Y$, Sekiguchi M (2001) Expression and prognostic significance of $O^{6}$ methylguanine-DNA methyltransferase in hepatocellular, gastric, and breast cancers. Ann Surg Oncol 8: 807-816 
Mikovits JA, Young HA, Vertino P, Issa JP, Pitha PM, Turcoski-Corrales S, Taub DD, Petrow CL, Baylin SB, Ruscetti FW (1998) Infection with human immunodeficiency virus type 1 upregulates DNA methyltransferase, resulting in de novo methylation of the gamma interferon (INF- $\gamma$ ) promoter and subsequent downregulation of INF- $\gamma$ production. Mol Cell Biol 18: $5166-5177$

Nakabeppu Y, Nathans D (1991) A naturally occurring truncated form of FosB that inhibits Fos/Jun transcriptional activity. Cell 64: 751-759

Okuda K (1992) Hepatocellular carcinoma: recent progress. Hepatology 15: $948-963$

Papadopoulos N, Nicolaides NC, Wei YF, Ruben SM, Carter KC, Rosen CA, Haseltine WA, Fleischmann RD, Fraser CM, Adams MD, Venter CJ, Hamilton SR, Petersen GM, Watson P, Lynch HT, Päeltomki P, Mecklin JP, de la Chapelle A, Kinzler KW, Vogelstein B (1994) Mutation of a $m u t L$ homolog in hereditary colon cancer. Science 263: 1625-1629

Paradis V, Laurendeau I, Vidaud M, Bedossa P (1998) Clonal analysis of macronodules in cirrhosis. Hepatology 28: 953-958

Paulin R, Grigg GW, Davey MW, Piper AA (1998) Urea improves efficiency of bisulphite-mediated sequencing of $5^{\prime}$-methylcytosine in genomic DNA. Nucleic Acids Res 26: 5009-5010
Pegg AE (1990) Mammalian $O^{6}$-alkylguanine-DNA alkyltransferase: regulation and importance in response to alkylating carcinogenic and therapeutic agents. Cancer Res 50: 6119-6129

Pogribny IP, Pogribna M, Christman JK, James SJ (2000) Single-site methylation within the $p 53$ promoter region reduces gene expression in a reporter gene construct: possible in vivo relevance during tumorigenesis. Cancer Res 60: $588-594$

Srivenugopal KS, Yuan XH, Friedman HS, Ali-Osman F (1996) Ubiquitination-dependent proteolysis of $O^{6}$-methylguanine-DNA methyltransferase in human and murine tumor cells following inactivation with $O^{6}$ benzylguanine or 1,3-bis (2-chloethyl)-1-nitrosourea. Biochemistry 35: $1328-1334$

Studier FW, Rosenberg AH, Dunn JJ (1990) Use of T7 RNA polymerase to direct expression of cloned genes. Methods Enzymol 185: 60-89

Sun L, Hui AM, Kanai Y, Sakamoto M, Hirohashi S (1997) Increased DNA methyltransferase expression is associated with an early stage of human hepatocarcinogenesis. Jpn J Cancer Res 88: 1165-1170

Wang L, Bani-Hani A, Montoya DP, Roche PC, Thibodeau SN, Burgart LJ, Roberts LR (2001) hMLH1 and hMSH2 expression in human hepatocellular carcinoma. Int J Oncol 19: 567-570 